\title{
HUBUNGAN UMUR IBU, PARITAS DAN PENOLONG PERSALINAN DENGAN KEMATIAN NEONATAL DI WILAYAH KERJA PUSKESMAS KABUPATEN BANJARNEGARA TAHUN 2013
}

\author{
Isnaeni Rofiqoch ${ }^{1}$, Jusuf S. Effendi², Dinan S. Bratakoesoema ${ }^{3}$
}

\begin{abstract}
Background: The neonatal mortality rate is Banjarnegara district is high compared with a target of IMR in Central Java province. In 2012 the neonatal mortality rate in Banjarnegara reached 316 cases, whereas in 2013 there were 115 cases in all health centers working area. The high neonatal mortality rate in Banjarnegara influenced by the persistence of early marriage in woman, birth attendant by non skilled health worker (dukun bayi) and women's parity more than 4.

Objective: The purpose of this study is to analyze the correlation between maternal age, parity and birth attendants with the incidence of neonatal mortality and examine the most dominant factors influencing the incidence neonatal mortality in the Health Center working area in Banjarnegara.

Method: This study is a case control study design with retrospective approach. The data consists of perinatal verbal autopsy and medical records as many as 136 respondents consisting of 68 mothers who gave birth to her child and neonatal death and 68 maternal and child alive. Subjects were mothers who gave birth a baby who died aged 0-28 days.

Result and Discussion: Statistical analysis using Chi Square, Mann Whitney, and multiple logistic regression. The results showed maternal age and parity variables were not significantly corerelated with neonatal mortality $(p>0.05)$, the variables significantly corerelated with neonatal mortality was birth attendants with $p=0.001$. The results of logistic regression showed the strength of the corerelation from the most dominant variable to the smallest variable were birth attendants with OR: 5.64 (95\% Cl: 1.81 to 17.4), maternal age OR 3.97 ( $\mathrm{Cl} 95 \%$, from 1.54 to 10.22), and parity OR: 0.32 (Cl 95\% 0.12 to 0.87 ).

Conclusion: In conclusion, there was no relationship between maternal age and parity with neonatal mortality but there was a relationship between birth attendants with neonatal mortality. Based on the results of the multivariable analysis, birth attendants' effect on the incidence of neonatal deaths was 5 times greater than mother's age and parity.
\end{abstract}

Keywords: Neonatal mortality, maternal age, parity, birth attendants

\begin{abstract}
ABSTRAK
Latar Belakang: Kematian neonatal di Kabupaten Banjarnegara mencapai 316 kasus pada tahun 2012. Tingginya kematian neonatal di Kabupaten Banjarnegara dipengaruhi oleh banyaknya pernikahan dini, persalinan oleh dukun dan masalah grandemultipara.
\end{abstract}

\footnotetext{
Mahasiswa Program Studi Magister Kebidanan, Fakultas Kedokteran Universitas Padjadjaran

Staf Pendidik Fakultas Kedokteran Universitas Padjadjaran

Staf Pendidik Fakultas Kedokteran Universitas Padjadjaran
} 
Tujuan: Tujuan penelitian ini adalah ingin menganalisis hubungan faktor umur ibu, paritas dan penolong persalinan dengan kematian neonatal di Wilayah Kerja Puskesmas Kabupaten Banjarnegara serta mengkaji faktor apa yang paling dominan mempengaruhi kematian neonatal.

Metode: Penelitian ini menggunakan rancangan Case Control dengan pendekatan retrospektif. Data kematian neonatal diperoleh dari catatan medik. Subjek penelitian adalah seluruh ibu yang melahirkan dan anaknya mengalami kematian usia 0-28 hari. Besar sampel yang digunakan adalah 68 reponden untuk masing-masing kelompok kasus dan kontrol.

Hasil dan Pembahasan: Analisis statistik menggunakan uji Chi Square, dan regresi logistik ganda. Hasil analisis menunjukkan bahwa penolong persalinan berhubungan secara signifikan dengan kematian neonatal dengan nilai $p<0,05$, sedangkan umur ibu dan paritas tidak berhubungan dengan kematian neonatal $(p>0,05)$. Hasil regresi logistik juga menunjukkan bahwa variabel dominan yang paling berhubungan dengan kematian neonatal adalah penolong persalinan dengan OR: 5,64 (IK 95\%: 1,81-17,4). Kesimpulan: Kesimpulan penelitian ini adalah terdapat hubungan antara penolong persalinan dengan kematian neonatal dan mempunyai pengaruh 5 kali lebih besar dibandingkan umur ibu dan paritas terhadap kematian neonatal.

Kata kunci: Kematian neonatal, umur ibu, paritas, penolong persalinan

\section{PENDAHULUAN}

Peningkatan kualitas kesehatan di suatu negara dimulai dari peningkatan kualitas kesehatan ibu dan bayi. Angka Kematian Neonatal (AKN) masih menjadi indikator keberhasilan pembangunan kesehatan yang dicanangkan oleh sistem kesehatan nasional Negara Republik Indonesia. World Health Organization (WHO) di dalam Millennium Development Goals (MDGs), menjelaskan bahwa target pada tahun 2015 AKN adalah sebesar 17 per 1000 kelahiran hidup. Ditinjau dari hasil Survey Demografi Kesehatan Indonesia (SDKI) 2007, AKN di Indonesia adalah 19/1000 kelahiran hidup (KH). Angka Kematian Bayi (AKB) di Propinsi Jawa Tengah tahun 2011 sebesar 10,34 per 1.000 kelahiran hidup sedangkan pada tahun 2012 mengalami kenaikan yaitu sebanyak 10,75 per 1.000 kelahiran hidup. Pada tahun 2013 kematian neonatal pada triwulan 2 sudah mencapai 2.364 kasus. $^{1-3}$

Data dari Dinas Kesehatan Kabupaten Banjarnegara untuk AKN ( 28 hari) dari tahun 2008 sampai dengan tahun 2012 mengalami peningkatan. Hal ini terlihat dari data tahun 2008 AKN sebanyak 202, tahun 2009 sebanyak 284, tahun 2010 sebanyak 196, tahun 2011 sebanyak 186, dan tahun 2012 sebanyak 316 atau sebanyak 18,2 per $1000 \mathrm{KH}$ dan pada tahun 2013 sampai dengan bulan Maret angka kematian neonatal sudah mencapai 67 kasus, angka ini masih sangat tinggi dibandingkan dengan target AKB di propinsi Jawa Tengah. AKN di Kabupaten Banjarnegara masih tinggi dibandingkan dengan kabupaten sekitarnya seperti Kabupaten Banyumas, Purbalingga dan Wonosobo. Kabupaten Banjarnegara merupakan penyumbang kematian bayi tertinggi di Propinsi Jawa Tengah berdarkan data profil kesehtan Propinsi Jawa Tengah tahun 2012.3-6

Faktor penyebab terjadinya kematian neonatal di Kabupaten Banjarnegara antara lain bayi berat lahir rendah (BBLR) dengan 93 kasus, asfiksia 29 kasus, infeksi 5 dan penyebab lain 21 kasus. Di Indonesia, BBLR merupakan penyebab kematian neonatal tertinggi yaitu $30,3 \%$ (Hermiyanti, 2005). Jarak kelahiran yang pendek 
akan menyebabkan seorang ibu belum cukup waktu untuk memulihkan kondisi tubuhnya setelah melahirkan sebelumnya, sehingga berisiko terganggunya sistem reproduksi yang akan berpengaruh terhadap berat lahir., ${ }^{7,9}$

Penelitian di Nigeria mendapatkan hasil bahwa faktor-faktor yang menyebabkan kematian neonatal adalah karakteristik ibu yang terdiri dari umur ibu, paritas, tingkat pendidikan, ANC yang lemah dan penyakit yang menyertai kehamilan. Hasil penelitian Gordon ${ }^{10}$ menjelaskan bahwa umur ibu saat hamil dan melahirkan kurang dari 20 tahun dan lebih dari 40 tahun memungkinkan terjadinya kematian neonatal tinggi. Hasil penelitian ini juga menjelaskan bahwa umur ibu saat hamil dan melahirkan lebih dari 40 tahun dan ibu dengan multipara kemungkinan terjadinya kematian neonatal lebih tinggi dibandingkan umur kurang dari 40 tahun dan ibu dengan nulipara. Selaras dengan penelitian di India yang menjelaskan bahwa umur ibu saat hamil dan melahirkan di atas 40 tahun berrisiko terjadinya kematian neonatal lebih tinggi dibandingkan dengan umur ibu saat hamil dan melahirkan antara 20-39 tahun. ${ }^{12,16-17}$

Faktor risiko terjadinya kematian neonatal tidak hanya terjadi pada ibu dengan umur muda atau ibu dengan umur lebih dari 40 tahun. Kematian neonatal juga dapat terjadi pada ibu dengan paritas tinggi. Paritas merupakan salah satu faktor risiko penyebab terjadinya kematian neonatal. Penelitian lain juga menjelaskan bahwa paritas merupakan faktor risiko terjadinya kematian neonatal seperti penelitian di India dan di Australia, ibu dengan paritas 1-2 berpeluang mengalami kematian neonatal lebih rendah dibandingkan ibu dengan paritas 3-4, akan tetapi ibu dengan paritas 3-4 kemungkinan lebih rendah mengalami kematian neonatal dibandingkan dengan ibu yang memiliki paritas lebih dari 5 . Ibu dengan paritas tinggi kemungkinan untuk mengalami kematian neoanatal juga akan semakin tinggi. ${ }^{16-17}$
Selain faktor ibu, faktor penolong persalinan juga menjadi faktor penyebeb terjadinya kematian neonatal. Persalinan yang di tolong oleh bidan lebih baik di bandingkan persalinan yang di tolong oleh dukun, karena persalinan yang ditolong oleh tenaga kesehatan kemungkinan untuk terjadinya kematian neonatal akan lebih kecil. ${ }^{18}$

Berdasarkan penelitian dari Prabamurti' ${ }^{12}$, angka kematian neonatal di Kabupaten Brebes Jawa Tengah berkaitan dengan umur ibu, paritas, berat badan lahir rendah, dan penolong persalinan. Analisis yang di gunakan dalam penelitian adalah case control dengan perbandingan kasus dan kontrol 1:1. Penelitian ini membuktikan bahwa umur ibu $(O R=7,69)$, paritas $(\mathrm{OR}=8,25)$, berat badan lahir $(\mathrm{OR}=6,07)$, penolong persalinan $(\mathrm{OR}=6,12)$ dan usaha nafas $(\mathrm{OR}=7,89)$ berhubungan dengan kematian neonatal.

Menurut data dari Departemen Kesehatan Republik Indonesia penyebab kematian neonatal di Indonesia dapat bermula dari masa kehamilan 28 minggu sampai hari ke-7 setelah persalinan (masa perinatal dan neonatal). Menurut teori Mosley and Chen ${ }^{17}$ faktor-faktor yang mempengaruhi kematian bayi antara lain faktor ibu, faktor pencemaran lingkungan, status gizi, cacat lahir, kontrol penyakit pribadi.

Cakupan persalinan oleh tenaga kesehatan di Kabupaten Banjarnegara tahun 2012 sebanyak 91,8 \% sedangkan persalinan oleh dukun atau sendiri sebanyak 107 (8,2 \%). Penolong persalinan di Kabupaten Banjarnegara 90\% adalah bidan akan tetapi masih ada masyarakat yang melakukan persalinan di bantu oleh tenaga dukun. Banyak alasan yang melatarbelakangi ibu dalam memilih penolong persalinan diantaranya adalah pengetahuan, sikap, budaya, keyakinan, faktor demografis, biaya, akses dan ketersediaan layanan kesehatan serta perilaku dari tokoh masyarakat dan tenaga kesehatannya ${ }^{4}$ 
Tingginya kematian neonatal sangat berpengaruh pada kualitas kesehatan. Propinsi Jawa Tengah merupakan salah satu propinsi yang mempunyai permasalahan kematian neonatal yang tinggi. Kematian neonatal berdasarkan SDKI (2012) mengalami puncaknya pada tahun 2011. Kabupaten Banjarnegara menempati urutan pertama dalam tingginya kematian neonatal. Tingginya kematian neonatal di Kabupaten Banjarnegara di pengaruhi oleh masih banyaknya pernikahan dini. Umur ibu yang masih muda berpengaruh pada pengetahuan tentang kehamilan dan persalinan yang masih rendah meski hal ini juga masih dapat teratasi dengan ANC yang berkualitas oleh bidan. Selain umur yang terlalu muda, masalah lain adalah grandemultipara yang juga menjadi salah satu penyebab terjadinya kematian neonatal. Data juga menunjukkan 107 (8,2\%) ibu bersalin di Kabupeten Banjarnegara masih di tolong oleh dukun. Faktor inilah yang masih menjadi kendala bagi Kabupaten Banjarnegara dalam menurunkan tingginya angka kematian neonatal. Tingginya angka kematian neonatal pada wilayah puskesmas di Kabupaten Banjarnegara membuat peneliti tertarik untuk meneliti hubungan umur ibu, paritas ibu dan penolong persalinan dengan kematian neonatal di wilayah kerja puskesmas Kabupaten Banjarnegara tahun 2013.

\section{METODE}

Penelitian menggunakan rancangan Case Control dengan pendekatan retrospektif. Subjek penelitian adalah seluruh ibu yang melahirkan dan anaknya mengalami kematian usia 0-28 hari. Besar sampel yang digunakan adalah 68 reponden untuk masing-masing kelompok kasus dan kontrol. Sampel yang digunakan adalah kasus dan kontrol yang memenuhi kriteria inklusi dan ekslusi. Analisis statistik menggunakan uji Chi Square, dan regresi logistik ganda.

\section{HASIL DAN PEMBAHASAN}

Tabel 1. Karateristik Responden

\begin{tabular}{lccccc}
\hline \multicolumn{1}{c}{$\begin{array}{c}\text { Karakteristik } \\
\text { responden }\end{array}$} & $\begin{array}{c}\text { Ya } \\
\mathrm{n}=68\end{array}$ & $\%$ & $\begin{array}{c}\text { Tidak } \\
\mathrm{n}=68\end{array}$ & Nematian neonatal \\
\cline { 2 - 4 } & 19 & 27,9 & 15 & 22,1 & 0,407 \\
\hline Umur ibu & 42 & 61,8 & 41 & 60,3 & \\
$<=20$ th & 7 & 10,3 & 12 & 17,6 & \\
21- 34 th & & & & & 0,772 \\
$>=35$ th & 31 & 45,6 & 35 & 51,5 & \\
\hline Paritas & 31 & 45,6 & 27 & 39,7 & \\
2-3 anak & 6 & 8,8 & 6 & 8,8 & \\
1 anak & & & & & \\
$>4$ anak & & & & \\
\hline
\end{tabular}

Ket.: uji chi kuadrat 
Berdasarkan hasil pada Tabel 1 di atas ditinjau dari karakteristik responden didapatkan hasil umur ibu mayoritas pada usia 21-34 tahun dan paritas pada 2-3 anak. Hasil uji statistik didapatkan nilai $p>0,05$ yang berarti bahwa tidak terdapat perbedaan pada umur ibu dan paritas pada kelompok kasus dan kelompok kontrol, sehingga kedua kelompok layak untuk dibandingkan.

Tabel 2. Hubungan variabel perancu dengan kematian neonatal

\begin{tabular}{|c|c|c|c|c|c|}
\hline \multirow{2}{*}{$\begin{array}{l}\text { Karakteristik } \\
\text { responden }\end{array}$} & \multicolumn{4}{|c|}{ Kematian neonatal } & \multirow[b]{2}{*}{ Nilai $\mathrm{p}$} \\
\hline & $\begin{array}{c}\mathrm{Ya} \\
\mathrm{n}=68\end{array}$ & $\%$ & $\begin{array}{l}\text { Hidup } \\
\mathrm{n}=68\end{array}$ & $\%$ & \\
\hline \multicolumn{6}{|l|}{ BBLR } \\
\hline Ya & 61 & 89,8 & 1 & 1,5 & 0,001 \\
\hline Tidak & 7 & 10,2 & 67 & 98,5 & \\
\hline \multicolumn{6}{|c|}{ Umur kehamilan } \\
\hline$>37$ minggu & 16 & 23,5 & 66 & 97,1 & 0,001 \\
\hline$<37$ minggu & 52 & 76,5 & 2 & 2,9 & \\
\hline \multicolumn{6}{|c|}{ Kel. Kongenital } \\
\hline Ya & 21 & 30,9 & 9 & 13,2 & 0,013 \\
\hline Tidak & 47 & 69,1 & 59 & 86,8 & \\
\hline \multicolumn{6}{|l|}{ Asfiksia } \\
\hline Ya & 58 & 85,2 & 3 & 4,4 & 0,001 \\
\hline Tidak & 10 & 14,8 & 65 & 95,5 & \\
\hline
\end{tabular}

Ket.: uji chi kuadrat

Hasil analisis Tabel 2 menunjukkan $p$ kongenital, dan asfiksia dengan kematian $<0,05$ yang artinya terdapat hubungan yang neonatal di wilayah kerja puskesmas kabupaten signifikan antara BBLR, umur kehamilan, kelainan Banjarnegara tahun 2013.

Tabel 3. Hubungan Karakteristik ibu dengan kematian neonatal

\begin{tabular}{lccccc}
\hline \multirow{2}{*}{$\begin{array}{l}\text { Karakteristik } \\
\text { responden }\end{array}$} & $\begin{array}{c}\text { Ya } \\
\mathrm{n}=68\end{array}$ & $\%$ & $\begin{array}{c}\text { Tidak } \\
\mathrm{n}=68\end{array}$ & $\%$ & Nilai $\mathrm{p}$ \\
\cline { 1 - 4 } $\begin{array}{l}\text { Umur Ibu } \\
<=20 \text { th }\end{array}$ & 19 & 27,9 & 15 & 22,1 & 0,407 \\
$21-34$ th & 42 & 61,8 & 41 & 60,3 & \\
$>=35$ th & 7 & 10,3 & 12 & 17,6 & \\
Paritas & & & & & \\
2-3 anak & 31 & 45,6 & 35 & 51,5 & 0,772 \\
1 anak & 31 & 45,6 & 27 & 39,7 & \\
$>4$ anak & 6 & 8,8 & 6 & 8,8 & \\
\hline
\end{tabular}

Ket.: uji Chi kuadrat 
Tabel 3. menunjukkan bahwa tidak ada hubungan yang signifikan antara umur ibu dan paritas dengan kematian neonatal di wilayah kerja puskesmas Kabupaten Banjarnegara tahun $2013(p>0,05)$.

Tabel 4. Hubungan penolong persalinan dengan kematian neonatal

\begin{tabular}{|c|c|c|c|c|c|}
\hline \multirow[b]{2}{*}{ Faktor } & \multicolumn{4}{|c|}{ Kematian neonatal } & \multirow[b]{2}{*}{ Nilai $p$} \\
\hline & $\begin{array}{c}\mathrm{Ya} \\
\mathrm{n}=68\end{array}$ & $\%$ & $\begin{array}{c}\text { Hidup } \\
\mathrm{n}=68\end{array}$ & $\%$ & \\
\hline \multicolumn{6}{|c|}{ Penolong persalinan } \\
\hline Dukun & 26 & 83,9 & 5 & 16,1 & 0,001 \\
\hline Bidan & 42 & 40,0 & 63 & 60,0 & \\
\hline
\end{tabular}

Ket.: berdasarkan uji chi kuadrat nilai $p<0,05$

Tabel 4 menunjukkan bahwa terdapat hubungan yang signifikan antara penolong persalinan dengan kematian neonatal di wilayah kerja puskesmas Kabupaten Banjarnegara tahun 2013 dengan nilai $(p<0,01)$.

\section{Analisis Multivariat Regresi Logistik}

Setelah melakukan analisis bivariabel yang digunakan untuk mengetahui keterkaitan kedua variabel maka analisis multivariabel dilakukan dengan tujuan untuk melihat dan mempelajari keterkaitan beberapa variabel. Variabel yang dimasukan ke dalam analisis multivariabel adalah yang pada analisis bivariabel mempunyai nilai $p<0,25$. Berdasarkan hasil analisis bivariabel yang telah dilakukan sebelumnya, variabel yang mempunyai nilai $p<0,25$ di antaranya adalah umur ibu, penolong persalinan dan paritas. Hasil akhir analisis multivariabel dengan menggunakan regresi logistik ganda dapat dilihat pada tabel berikut.

Tabel 5. Faktor yang berhubungan dengan kematian neonatal berdasarkan analisis regresi logistik ganda

\begin{tabular}{lcccc}
\hline Variabel & Koefisien $\beta$ & SE $\beta$ & Nilai $p$ & OR (IK 95\%) \\
\hline Umur Ibu & 1,378 & 0,483 & 0,004 & $3,97(1,53-10,2)$ \\
Penolong Persalinan & 1,729 & 0,578 & 0,003 & $5,64(1,81-17,4)$ \\
Paritas & 1,146 & 0,513 & 0,026 & $0,32(0,12-0,87)$ \\
Constanta & 1,860 & 0,627 & & \\
\hline
\end{tabular}

Hasil analisis regresi logistik seperti pada Tabel 5 menunjukkan bahwa variabel yang berhubungan secara signifikan dengan kematian neonatal adalah variabel umur ibu, penolong persalinan dan paritas. Kekuatan hubungan dari yang terbesar hingga yang terkecil adalah penolong persalinan (OR=5,64; IK 95\%: 1,82-
17,49), umur ibu (OR=3,97; IK 95\%: 1,54-10,22) dan paritas (OR=0,32; IK 95\%: 0,12-0,87).

\section{Hubungan antara umur ibu dengan kematian} neonatal

Hasil penelitian menunjukkan bahwa tidak terdapat hubungan antara umur ibu dengan 
kematian neonatal. Hal tersebut dapat terlihat dari hasil analisis umur ibu pada Tabel 3 yang menunjukkan bahwa nilai $p=0,407(p>0,05)$ yang artinya tidak terdapat hubungan yang bermakna antara umur ibu dengan kematian neonatal. Sesuai dengan penelitian di Tazania yang menyatakan bahwa umur ibu tidak berhubungan secara signifikan dengan kematian neonatal. Umur ibu yang aman untuk melahirkan adalah umur antara 20 sampai umur 34 tahun karena pada umur ini risiko untuk terjadinya kematian ibu dan kematian bayi lebih sedikit dibandingkan dengan umur $<20$ tahun dan lebih dari 35 tahun.

Umur merupakan salah satu faktor yang dapat menggambarkan kematangan seseorang baik secara fisik, psikis maupun sosial, semakin bertambahnya umur seseorang maka bertambah pula pengetahuan yang didapat. Banyak wanita yang hamil di atas 35 tahun berhasil menjalankan kehamilan yang sehat dan melahirkan bayinya dengan selamat. Risiko terjadinya kesakitan dan kematian pada umur yang lebih tua dapat diminimalisir dengan perawatan kehamilan yang teratur, informasi tentang kehamilan dan persalinan yang lebih lengkap tentang tandatanda bahaya kehamilan dan kehamilan risiko tinggi, serta pertolongan tenaga kesehatan yang kompeten akan membantu ibu untuk tetap sehat pada masa kehamilan, persalinan dan nifas.

\section{Hubungan antara paritas dengan kematian neonatal}

Hasil analisis pada Tabel 3 menyatakan bahwa tidak terdapat hubungan antara paritas dengan kematian neonatal, terlihat dari nilai $p=0,772$ $(p>0,05)$. Tidak terdapatnya hubungan antara paritas dengan kematian neonatal di wilayah kerja puskesmas Kabupaten Banjarnegara dimungkinkan karena ibu yang melahirkan banyak terjadi di paritas 2-3 dan umur ibu terbanyak pada umur 20-34 tahun. Paritas 2-3 dengan umur 20-34 tahun bukan merupakan faktor risiko terjadinya kematian neonatal. Hal ini sesuai dengan penelitian-penelitian lain yang menunjukkan bahwa bahwa ibu dengan multiparitas dan umur ibu berkisar antara 2034 tahun memiliki risiko terjadinya kematian neonatal lebih kecil di bandingkan dengan ibu primipara umur kurang dari 20 tahun dan multipara dengan umur ibu lebih dari 35 tahun.

Penelitian ini menunjukkan bahwa ibu yang melahirkan bayinya lebih dari 4 sudah sedikit, sedangkan beberapa teori dan penelitian lain juga menjelaskan bahwa paritas 4 atau lebih bukan merupakan salah satu faktor penyebab terjadinya kematian neonatal. Terlihat jelas dari data penelitian bahwa ibu dengan paritas 4 atau lebih hanya terdapat 6 responden sedangkan paritas 2 atau 3 yang bukan merupakan faktor penyebab terjadinya kematian neonatal dan didukung dengan umur kehamilan yang aman yaitu ibu dengan umur 21-34 tahun mendominasi data hasil pada penelitian ini yaitu sebanyak 36 responden. Hal ini dimungkinkan masyarakat Kabupaten Banjarnegara sudah sadar akan faktor risiko terjadinya kematian neonatal dan masyarakat juga sudah sadar tentang berkB sehingga kesimpulan pada penelitian ini adalah tidak terdapat hubungan yang positif antara paritas dengan kematian neonatal di wilayah kerja puskesmas Kabupaten Banjarnegara tahun 2013.

\section{Hubungan antara penolong persalinan dengan kematian neonatal}

Tabel 4 menunjukkan bahwa terdapat hubungan antara penolong persalinan dengan kematian neonatal. Hal ini ditunjang dari hasil analisis dengan nilai $p<0,01$ yang artinya terdapat hubungan yang bermakna antara penolong persalinan dengan kematian neonatal di wilayah kerja puskesmas Kabupaten Banjarnegara tahun 2013. 
Data di atas sesuai dengan penelitian pada tahun 2006 di Tapanuli Utara yang mendapatkan hasil bahwa ibu yang persalinannya ditolong bukan oleh tenaga kesehatan mempunyai risiko 5 kali lebih besar terjadi kematian neonatal dibandingkan dengan ibu yang persalinannya di tolong oleh tenaga kesehatan. Hal ini juga diperjelas dengan penelitian lain di Brebes yaitu penelitian studi kasus kontrol yang menunjukkan bahwa penolong persalinan bukan oleh tenaga kesehatan memiliki risiko untuk mengalami kematian neonatal 6 kali lebih besar bila di bandingkan dengan ibu yang bersalin di tolong oleh petugas kesehatan.

Penelitian ini juga menunjukkan bahwa penolong persalinan sebagian besar masih dilakukan oleh dukun atau persalinan sendiri. Hasil analisis menunjukkan secara jelas bahwa ada 26 responden yang persalinannya ditolong oleh tenaga dukun. Hal ini dikarenakan masih banyaknya masyarakat yang percaya dengan dukun untuk membantu menolong persalinan. Mereka mengganggap bahwa dukun lebih baik di bandingkan bidan. Dukun tidak hanya menolong proses persalinan tetapi juga membantu ibu bersalin setelah proses persalinan selesai.

Berdasarkan penelitian yang dilakukan oleh peneliti lain menjelaskan bahwa faktor pemilihan tenaga penolong persalinan dipengaruhi oleh beberapa faktor di antaranya pengetahuan, pelayanan antenatal, kepercayaan pada pelayanan antenatal dan sosial budaya. Hasil penelitian univariabel dari kelima faktor di atas yang berhubungan paling kuat adalah faktor kepercayaan dan sosial budaya. Hal ini dikarenakan faktor kepercayaan dan sosial budaya berhubungan dengan cara pandang masyarakat terhadap apa yang telah mereka lakukan secara turun temurun dan telah terbukti kemampuannya dalam memberi pertolongan persalinan. Dukun/ paraji bersedia merawat sampai beberapa hari setelah melahirkan, melakukan pemijatan pada ibu setelah melahirkan, serta pemberian doadoa untuk keselamatan ibu dan anaknya.

Selain karena faktor-faktor di atas pada penelitin ini juga menemukan bahwa alasan masyarakat menggunakan tenaga dukun untuk menolong persalinan adalah karena ibu yang bersalin di tolong oleh tenaga dukun adalah ibu bersalin yang bermasalah, misalnya ibu yang hamil dan tidak menginginkan kehamilannya, ibu yang hamil di luar nikah, atau ibu dengan gagal berkB dan lain sebagainya.

\section{Faktor yang paling dominan sebagai penyebab kematian neonatal}

Hasil analisis regresi logistik ganda menujukan hasil bahwa ada beberapa faktor yang berrisiko menyebabkan kematian neonatal di antaranya umur ibu, paritas dan penolong persalinan. Dibandingkan dengan umur ibu dan paritas, penolong persalinan merupakan faktor risiko paling dominan berhubungan dengan kematian neonatal. Hasil analisis regresi logistik ganda menunjukkan nilai $p=0,003$ dan $O R=5,64$ $(1,81-17,4)$ yang artinya penolong persalinan memiliki risiko 5 kali lebih besar terhadap kematian neonatal, sedangkan untuk umur ibu menunjukkan nilai $\mathrm{OR}=3,97$ dan paritas menunjukkan nilai $\mathrm{OR}=0,32$.

Penolong persalinan menjadi faktor yang paling kuat atau paling dominan berhubungan dengan kematian neonatal dikarenakan masih cukup tinggi ibu yang bersalin ditolong oleh dukun. Penyebab masih tingginya persalinan yang dilakukan oleh tenaga dukun adalah dikarenakan kehamilan yang bermasalah atau kehamilan yang tidak diinginkan. Faktor geografis kabupaten Banjarnegara juga berpengaruh pada pemilihan penolong persalinan karena sebagian besar wilayahnya pegunungan sehingga masyarakat sulit untuk mendapatkan akses ke pusat kesehatan. Budaya masyarakat yang telah mereka lakukan secara turun temurun dalam 
pemilihan dukun untuk memberi pertolongan persalinan, serta bersedia merawat sampai beberapa hari setelah melahirkan, melakukan pemijatan pada ibu setelah melahirkan, serta pemberian doa-doa untuk keselamatan ibu dan anaknya sehingga ibu yang akan bersalin merasa aman dan percaya jika pada saat proses persalinannya yang menolong adalah orang yang dianggap lebih tua (dukun bayi) dan ditemani oleh keluarga terdekat terutama orang tuanya.

\section{KESIMPULAN}

1. Tidak terdapat hubungan antara umur ibu dengan kematian neonatal

2. Tidak terdapat hubungan antara paritas dengan kematian neonatal

3. Terdapat hubungan antara penolong persalinan dengan kematian neonatal.

4. Penolong persalinan merupakan faktor yang paling dominan berpengaruh terhadap kematian neonatal di wilayah kerja Kabupaten Banjarnegara tahun 2013.

\section{DAFTAR PUSTAKA}

1. SDKI. Survei Demografi dan Kesehatan Indonesia. Jakarta: Badan Pusat Statistik Indonesia;2012. Available from: http://www.bkkbn.go.id

2. Dinkes PJ. Profil Kesehatan Propinsi Jawa Tengah. Semarang 2011. Available from: http://www. dinkesjatengprov.go.id

3. Dinkes, Jateng. Buku Saku Kesehatan Triwulan 2 Tahun 2013. Semarang: Dinas Kesehatan Propinsi Jawa Tengah; 2013. Available from: http://www. dinkesjatengprov.go.id.

4. Dinkes PJ. Buku Saku Kesehatan tahun 2012. Semarang: Dinas Kesehatan Propinsi Jawa Tengah;

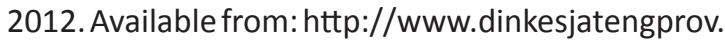
go.id

5. Banjarnegara DKK. Data laporan PWS KIA. Banjarnegara: Dinas Kesehatan Banjarnegara; 2012.
6. Dinkes, Jateng. Profil Kesehatan Propinsi Jawa Tengah Tahun 2012. In: DJBKM, editor. Semarang: Dinas Kesehatan Propinsi Jawa tengah; 2012.

7. Ota E. Maternal body mass index and gestational weight gain and their association with perinatal outcomes in Vietnam. Bulletin of the World Health Organization. 2010.

8. Proverawati A, Misaroh S. Nutrisi Untuk Janin dan Ibu Hamil. Yogyakarta: Nuha Medika; 2010.

9. Wortington R, Williams S. Nutrition Throughout The Life Cycle. McGraw-Hill International Editions. 2002;48-52.

10 Gordon A, Raynes-Greenow C, McGeechan K, Morris J, Jeffery $\mathrm{H}$. Risk factors for antepartum stillbirth and the influence of maternal age in New South Wales Australia: A population based study. BMC Pregnancy dan childbirth. 2007.

11. Lisonkova S, Janssen PA, sheps SB. the Effect Of Maternal Age on Adverse Birth Outcomes: Does Parity Matter. June JOGC Juin. [obstetrics and gynaecology]. 2009:541-8.

12. Prabamurti PN, Purnami CT, Widagdo L, Setyono S. Analisis Faktor Risiko Status Kematian Neonatal. Jurnal Promosi Kesehatan Indonesia. 2006.; Vol 3 No. 1.

13. Abdhi T. Determinan Pemanfaatan Dukun Bayi Oleh Masyarakat Dalam Pilihan Pertolongan Persalinan di Desa Anak Talang Kecamatan Batang Kabupaten Indragiri Hulu, 2010: Available from: www. respository.usu.ac.id/

14. BPS-SDKI. Survai Demografi Dan Kesehatan Indonesia 2007: Available from: www.bps.go.id.

15. Neonatal intensive-care unit admission of infants with very low birth weight --- 19 States, 2006. MMWR Morb Mortal Wkly Rep. 2010 Nov 12;59(44):1444-7.

16. Burhan, Budhi S. Pedoman praktis safe motherhood perawatan dalam kelahiran normal pedoman praktis. Jakarta: EGC; 2003.

17. Mosley WH and Chen LC. AN analytical framework for the study of child survival in developing countries. Population and Development Review 10(suppl.):25-45, 1984. 